\title{
Inhibitory effect of bone morphogenetic protein-2 on the proliferation of giant cell tumor of bone stromal cells in vitro
}

\author{
BAOHUA HE ${ }^{1,2^{*}}$, GUANPING HE ${ }^{2 *}$, XIAOFEI ZHENG ${ }^{3}$, LIHUA LI $^{3}$, MEI LI $^{3}$ and HONG XIA ${ }^{3}$ \\ ${ }^{1}$ Department of Orthopedics, China Meitan General Hospital, Beijing 100028; ${ }^{2}$ Southern Medical University, \\ Guangzhou, Guangdong 510515; ${ }^{3}$ Department of Orthopedics, Guangzhou Liu Hua Qiao Hospital, \\ Guangzhou, Guangdong 510010, P.R. China
}

Received October 9, 2014; Accepted September 7, 2015

DOI: $10.3892 / \mathrm{etm} .2015 .2856$

\begin{abstract}
The inhibitory effect of bone morphogenetic protein-2 (BMP-2) on the proliferation of giant cell tumor of bone stromal cells (GCTSCs) has not been fully elucidated. Therefore, the aim of this study was to evaluate the role of recombinant human BMP-2 (rhBMP-2) in the growth of GCTSCs. The effects of exposure to different concentrations of rhBMP-2 $(0,10,100$ and $300 \mathrm{ng} / \mathrm{ml})$ for $1,3,5$ and 7 days on GCTSC proliferation were examined by 3-(4,5-dimethylthiazol-2-yl)-2,5-diphenyltetrazolium bromide (MTT) assay. In addition, the effect of treatment with rhBMP-2 $(0$ or $10 \mathrm{ng} / \mathrm{ml})$ for $48 \mathrm{~h}$ on the cell cycle pattern of GCTSCs was examined by flow cytometry. The apoptosis-inducing effect of rhBMP-2 ( 0 or $10 \mathrm{ng} / \mathrm{ml}$ ) in GCTSCs was also determined by flow cytometry after 48 and $72 \mathrm{~h}$. In addition, western blot assays were conducted to determine whether rhBMP-2 acts on non-Smad mitogen-activated protein kinase (MAPK) signaling pathways, namely extracellular signal-regulated kinase (ERK1/2), p38 and c-jun-N-terminal kinase (JNK) pathways. The proliferation of GCTSCs treated with rhBMP-2 $(10,100$ or $300 \mathrm{ng} / \mathrm{ml})$ for 5 or 7 days was significantly inhibited in a non dose-dependent and non-time-dependent manner $(\mathrm{P}<0.05)$. The treatment of GCTSCs with rhBMP-2 $(10 \mathrm{ng} / \mathrm{ml})$ for $48 \mathrm{~h}$ had no effect on cell cycle distribution. The apoptosis of GCTSCs induced by exposure to rhBMP-2 $(10 \mathrm{ng} / \mathrm{ml})$ for 48 or $72 \mathrm{~h}$ was significant $(\mathrm{P}<0.05)$. Expression levels of phospho-ERK1/2, phospho-p38 and phospho-JNK increased significantly when GCTSCs were treated with rhBMP-2 $(10 \mathrm{ng} / \mathrm{ml})$ for $72 \mathrm{~h}(\mathrm{P}<0.05)$. The results indicate that rhBMP-2 has no stimulatory effect on GCTSC
\end{abstract}

Correspondence to: Dr Xiaofei Zheng, Department of Orthopedics, Guangzhou Liu Hua Qiao Hospital, 111 Liuhua Road, Guangzhou, Guangdong 510010, P.R. China

E-mail: xiaofeizhengcn@126.com

*Contributed equally

Key words: recombinant human bone morphogenetic protein-2, giant cell tumor of bone, apoptosis, cell cycle, adjuvant management growth. However, it may lead to the apoptosis of GCTSCs by non-Smad MAPK signaling pathways.

\section{Introduction}

Giant cell tumor of bone (GCT) is a rare and commonly benign tumor that accounts for $\sim 5 \%$ of primary bone tumors and $15-20 \%$ of all benign bone tumors in adults $(1,2)$. GCT also exhibits a slight increase in prevalence in females and usually occurs in the third and fourth decades of life (1). Surgical curettage is a preferred treatment; however, it may be associated with a high local recurrence rate (18-50\%) and occasionally lung metastasis $(3,4)$. Recently, less-aggressive surgical resection, followed by extended intralesional curettage and cementation (or bone graft) with or without the use of adjuvant therapies, such as physical methods (blurring, hypothermic or hyperthermic reagents), chemical methods (phenol or hydrogen peroxide) and biologic modalities (bisphosphonates, interferon or denosumab) have been used to eliminate tumor remnants $(1,3,5,6)$.

GCTs have been found to include three major cell types: Multinucleated giant cells that express calcitonin receptors, tartrate-resistant acid phosphatase activity and other phenotypic osteoclast markers; a CD68-positive monocyte or macrophage population; and mononuclear fibroblast-like stromal cells that are able to proliferate in cell culture. Stromal cells are likely to be the neoplastic components of this tumor and regulate the formation of osteoclast-like giant cells in the neoplasm (7).

Bone morphogenetic proteins (BMPs), members of the transforming growth factor- $\beta$ superfamily, were originally studied as inducers of bone and cartilage formation and are also regulators of human carcinoma cell differentiation, proliferation, morphogenesis and apoptosis (8-10). BMP-2 exhibits potent activity in the induction of cartilage and bone formation in vivo and in vitro $(11,12)$. BMP-2 also plays key roles in cell proliferation, chemotaxis, angiogenesis, apoptosis and differentiation (13-17). The effects of BMP-2 are mediated via serine-threonine kinase receptors: BMP receptor type 1A (BMPR1A), BMPR1B and BMPR2. When BMPR2 is activated by binding to BMP-2, this induces the phosphorylation of BMPR1A and the recruitment of downstream signaling Smad1, Smad5 and Smad8 (receptor-regulated 
Smads), which then form heteromeric complexes with Smad4 (common-mediator Smad), and translocate to the nucleus to regulate the transcription of target genes $(18,19)$. In addition, non-Smad mitogen-activated protein kinase (MAPK) pathways including p38, c-jun-N-terminal kinase (JNK) and extracellular signal-regulated kinase (ERK1/2) pathways, which are also important in cell proliferation and differentiation, may be activated by BMP (20-22).

Since its approval by the US Food and Drug Administration (FDA) in 2002, recombinant human bone morphogenetic protein-2 (rhBMP-2) has become one of the most commonly used bone graft substitutes. A previous study revealed that GCT stromal cells (GCTSCs) might have the ability to differentiate into osteoblasts that are responsive to BMP-2 (23). However, the role of BMP-2 in GCTSCs remains unclear. The inhibitory effect of BMP-2 on GCTSC proliferation has been investigated in only a few in vitro studies $(23,24)$, and no in vivo studies. Therefore, preclinical studies are required to evaluate the effect of BMP-2 on tumor growth. The purpose of the present study was to assess whether rhBMP-2 promotes or suppresses GCT growth in vitro. The results may provide background data useful in the evaluation of the potential of rhBMP-2 as an adjuvant therapy for patients following the removal of GCT by surgery.

\section{Materials and methods}

Specimens. This study was conducted in accordance with the Declaration of Helsinki and with approval from the Ethics Committee of Guangzhou Liu Hua Qiao Hospital (Guangzhou, China). Written informed consent was obtained from all participants. Nine GCT specimens were freshly harvested and then used for primary cell culture. None of the patients had taken any medication prior to the surgery. Clinical information for each patient is not shown. The initial diagnosis was established via frozen section in the operating room and was later confirmed by permanent histological examination. A board-certified pathologist reviewed each sample to confirm the viability $(>80 \%$ by nuclei counts of hematoxylin and eosin-stained sections) and tumor content $(>90 \%)$ of each sample. Planned analyses were performed on each specimen as sample size allowed.

Cell cultures. In brief, freshly obtained GCT tissues were chopped up in Dulbecco's minimum essential medium (DMEM) containing 10\% fetal bovine serum (FBS), $100 \mathrm{U} / \mathrm{ml}$ penicillin and $100 \mathrm{mg} / \mathrm{ml}$ streptomycin. The resultant cell suspension together with small pieces of tissues was transferred to culture flasks and cultured at $37^{\circ} \mathrm{C}$ in a humidified atmosphere of $5 \% \mathrm{CO}_{2}$ and $95 \%$ air. Half of the culture medium was changed every 2-3 days. Upon reaching confluence, primary cultures were then subcultured. GCTSCs in cultures obtained after the 9th passage (Fig. 1) were studied.

3-(4,5-Dimethylthiazol-2-yl)-2,5-diphenyltetrazolium bromide

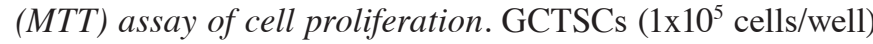
were plated and cultured in 96-well plates with rhBMP-2 (R\&D Systems, Inc., Minneapolis, MN, USA) at concentrations of $0,10,100$ and $300 \mathrm{ng} / \mathrm{ml}$ in DMEM containing $10 \%$ FBS for 1, 3, 5 or 7 days. MTT (Sigma-Aldrich, St. Louis,

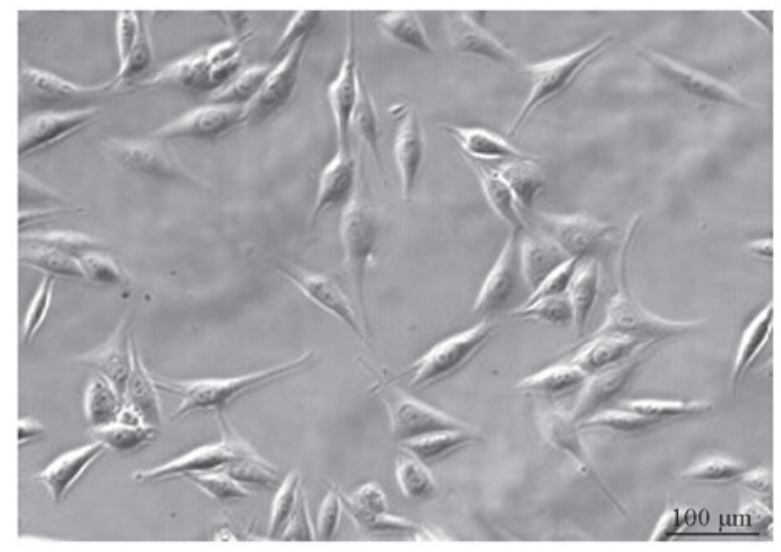

Figure 1. GCTSCs are purified after the 9th passage, which represents the proliferating homogenous tumor cell population (original magnification, $\mathrm{x} 100)$. GCTSC, giant cell tumor of bone stromal cell.

MO, USA) was added to the culture medium according to the manufacturer's instructions, and the culture was continued for another $4 \mathrm{~h}$. Dimethylsulfoxide (100 $\mu \mathrm{l} /$ well) was added to each well to dissolve the formazan crystals. The optical density of the resulting product was measured at $490 \mathrm{~nm}$ using a microplate reader (Multiskan GO; Thermo Fisher Scientific, Waltham, MA, USA).

Flow cytometric analysis. Cell cycle conditions were determined by fluorescence-activated cell sorting (FACS) analysis using propidium iodide (PI) staining. GCTSCs in the logarithmic phase of growth were incubated in the presence or absence of rhBMP-2 $(10 \mathrm{ng} / \mathrm{ml})$ in 10\% FBS DMEM for $48 \mathrm{~h}$. The cells were then harvested and washed in cold phosphate-buffered saline (PBS; pH 7.4). The cell pellets were fixed in $70 \%$ cold alcohol for $>24 \mathrm{~h}$ at $4^{\circ} \mathrm{C}$, then washed in cold PBS and stained with PI solution at $4^{\circ} \mathrm{C}$ in the dark for $30 \mathrm{~min}$. Apoptosis induced by rhBMP-2 in GCTSCs was determined by flow cytometry using the Guava Nexin Reagent kit (EMD Millipore, Billerica, MA, USA), according to the manufacturer's instructions. Briefly, treated or untreated cells were collected, washed in cold PBS and centrifuged at $200 \mathrm{xg}$ for $5 \mathrm{~min}$. The cell pellets were resuspended in $100 \mathrm{ml}$ DMEM supplemented with $1 \%$ FBS, and then incubated with $100 \mathrm{ml}$ Annexin V-PE and 7-aminoactinomycin D labeling solution for $20 \mathrm{~min}$ at room temperature. Cells were finally analyzed with a Guava EasyCyte 5HT flow cytometer (EMD Millipore). The data were analyzed using Guava Nexin Software, version 2.2.2 (EMD Millipore).

Western blot analysis. Cells were seeded in 6-well plates at a density of $1 \times 10^{6}$ cells/well. After being allowed to adhere overnight, the cultures were cultured in the presence or absence of rhBMP-2 $(10 \mathrm{ng} / \mathrm{ml})$ in 10\% FBS DMEM for $72 \mathrm{~h}$. After the treatment period, cells were washed with PBS and then resuspended in lysis buffer [1\% NP-40, $1 \mathrm{mmol} / 1$ phenylmethylsulfonyl fluoride, $40 \mathrm{mmol} / \mathrm{l}$ Tris- $\mathrm{HCl}(\mathrm{pH} \mathrm{8.0)}$ ), $\left.150 \mathrm{mmol} / \mathrm{l} \mathrm{NaCl}, 100 \mathrm{mmol} / \mathrm{l} \mathrm{Na} \mathrm{VO}_{4}, 1 \mathrm{mmol} / \mathrm{l} \mathrm{NaF}\right]$ at $4^{\circ} \mathrm{C}$ for $15 \mathrm{~min}$. Protein concentrations were determined by means of a Bio-Rad protein assay (Bio-Rad, Richmond, CA, USA). The proteins were separated by $10 \%$ sodium dodecyl 


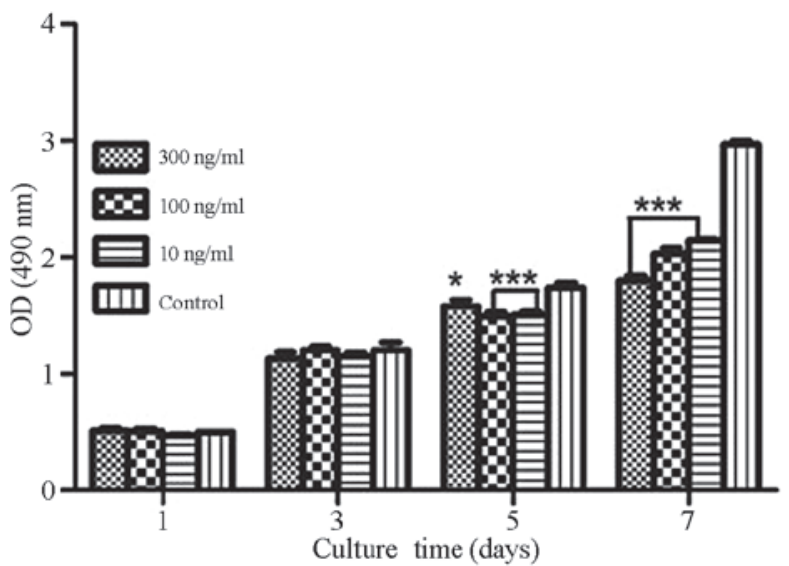

Figure 2. Effects of different concentrations of rhBMP-2 on GCTSC proliferation as evaluated using an MTT assay. GCTSCs were incubated with different concentrations of rhBMP-2 in DMEM containing $10 \%$ FBS for 1, 3, 5 or 7 days. Data are presented as the mean \pm standard deviation $(\mathrm{n}=3)$. ${ }^{*} \mathrm{P}<0.05,{ }^{* * * *} \mathrm{P}<0.01$ vs. control. rhBMP-2, recombinant human bone morphogenetic protein-2; GCTSC, giant cell tumor of bone stromal cell; MTT, 3-(4,5-dimethylthiazol-2-yl)2,5-diphenyltetrazolium bromide; DMEM, Dulbecco's minimum essential medium; FBS, fetal bovine serum; OD, optical density.
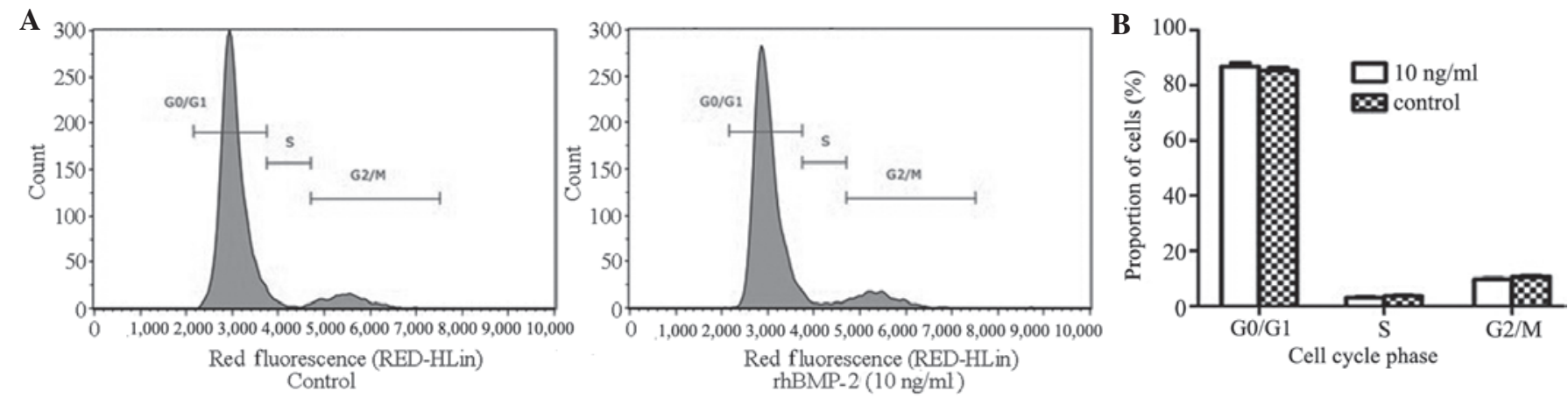

Figure 3. Effects of rhBMP-2 on the cell cycle pattern of GCTSCs. GCTSCs were treated with different concentrations of $\mathrm{rhBMP}-2$ (10 ng/ml) for $48 \mathrm{~h}$. (A) Representative histograms of cell cycle processes in control and rhBMP-2-treated cells are shown. (B) Bar plots indicating the percentages of cells in the G0/G1, S and G2/M phases of GCTSCs. Data points in the graph are the mean \pm standard deviation of three independent experiments. rhBMP-2, recombinant human bone morphogenetic protein-2; GCTSC, giant cell tumor of bone stromal cell.

sulfate-polyacrylamide gel electrophoresis (SDS-PAGE) and transferred to polyvinylidene difluoride (PVDF) membranes (EMD Millipore). After blocking with 5\% non-fat dry milk, each blot was probed with a primary antibody $(1: 1,000)$ directed against ERK1/2 (rabbit monoclonal; cat. no. 4695), p38 MAPK (rabbit monoclonal; cat. no. 8690), JNK (rabbit monoclonal; cat. no. 9252), phospho-Erk1/2 (rabbit monoclonal; cat. no. 4094), phospho-p38 MAPK (rabbit monoclonal; cat. no. 4511) or phospho-JNK (mouse monoclonal; cat. no. 9255) (Cell Signaling Technology, Danvers, MA, USA) at $4^{\circ} \mathrm{C}$ overnight. Subsequently, the membranes were washed three times ( $5 \mathrm{~min} / \mathrm{wash})$ with Tris-buffered saline containing $0.05 \%$ Tween-20 (TBST). The membranes were then incubated for $30 \mathrm{~min}$ at room temperature with a peroxidase-conjugated AffiniPure goat anti-rabbit IgG secondary antibody (1:3,000; cat. no. 111-035-003; Jackson Immunoresearch Laboratories, Inc., West Grove, PA, USA). The membranes were washed a further three times with TBST and incubated with Super Signal Enhanced Chemiluminescence substrate (Detection Reagents 1 and 2 at a 1:1 ratio; Pierce Biotechnology, Inc., Rockford, IL, USA) for $1 \mathrm{~min}$ at $25^{\circ} \mathrm{C}$. After removing the excess mixture, the blots were wrapped in a clean piece of plastic wrap, ensuring no bubbles were present between the blot and wrap. The blots were then exposed for 30-300 sec to X-ray film (Eastman Kodak, Rochester, NY, USA). Band intensities were quantified using Quantity One software (v. 4.4.0; Bio-Rad Laboratories, Inc., Hercules, CA, USA) by two observers who were blind to the experimental groups.

Statistical analysis. The results are expressed as the mean \pm standard deviation. The statistical analyses were conducted using SPSS 19.0 (IBM SPSS, Armonk, NY, USA) statistical software. The photometric values obtained in MTT assays were analyzed by one-way analysis of variance, with post-hoc multiple comparisons made between groups using a least significant difference test. The comparisons between cell cycle alterations, cell apoptosis, and the expression of Erk1/2, p38 and JNK in the rhBMP2 $(10 \mathrm{ng} / \mathrm{ml})$ and control groups were conducted using independent sample t-tests. $\mathrm{P}<0.05$ was considered to indicate a statistically significant difference.

\section{Results}

MTT assay. As shown in Fig. 2, growth of the GCTSCs was significantly inhibited by the addition of 10 or $100 \mathrm{ng} / \mathrm{ml}$ rhBMP-2 $(\mathrm{P}<0.01)$ or $300 \mathrm{ng} / \mathrm{ml}$ rhBMP-2 $(\mathrm{P}<0.05)$ for 5 days 
$\mathbf{A}_{\mathbf{a}}$

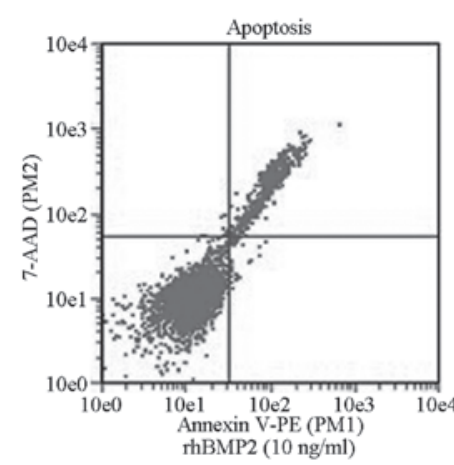

B

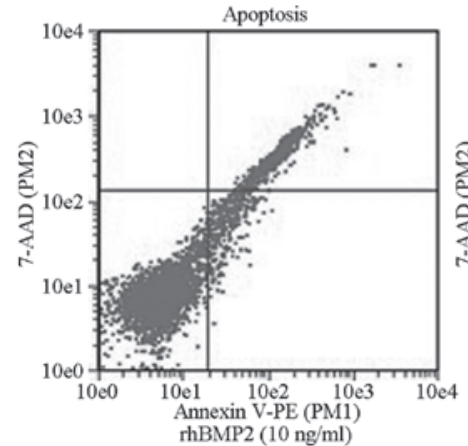

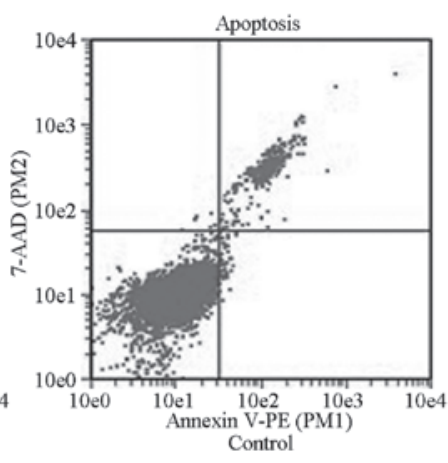

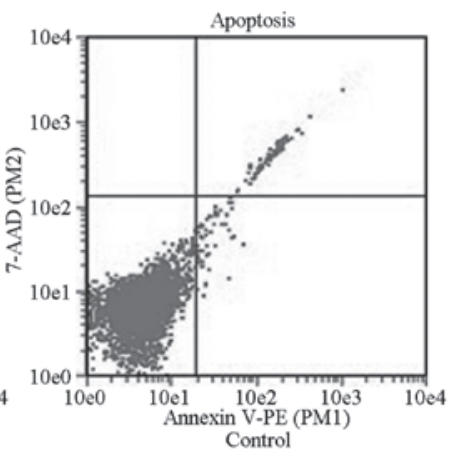

b

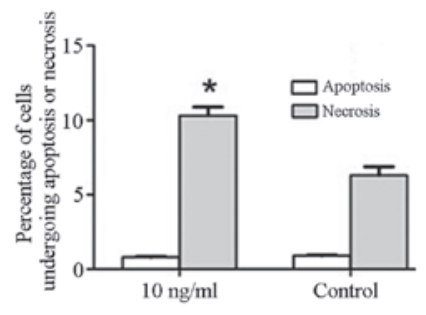

b

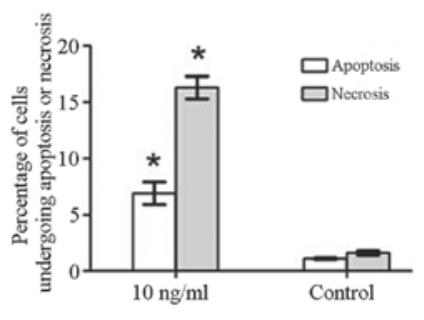

Figure 4. Apoptosis and necrosis of GCTSCs incubated with rhBMP-2 (10 ng/ml) in 10\% FBS DMEM medium for (A) $48 \mathrm{~h}$ and (B) $72 \mathrm{~h}$. (a) Representative dot plots of apoptosis in control and rhBMP-2-treated cells. (b) Bar plots indicating the percentage of apoptotic or necrotic GCTSCs in the control and rhBMP-2-treated groups. Results are means \pm SD of three independent experiments. " $\mathrm{P}<0.05$ compared with the control group. GCTSC, giant cell tumor of bone stromal cell; rhBMP-2, recombinant human bone morphogenetic protein-2; FBS, fetal bovine serum; DMEM, Dulbecco's minimum essential medium.

A

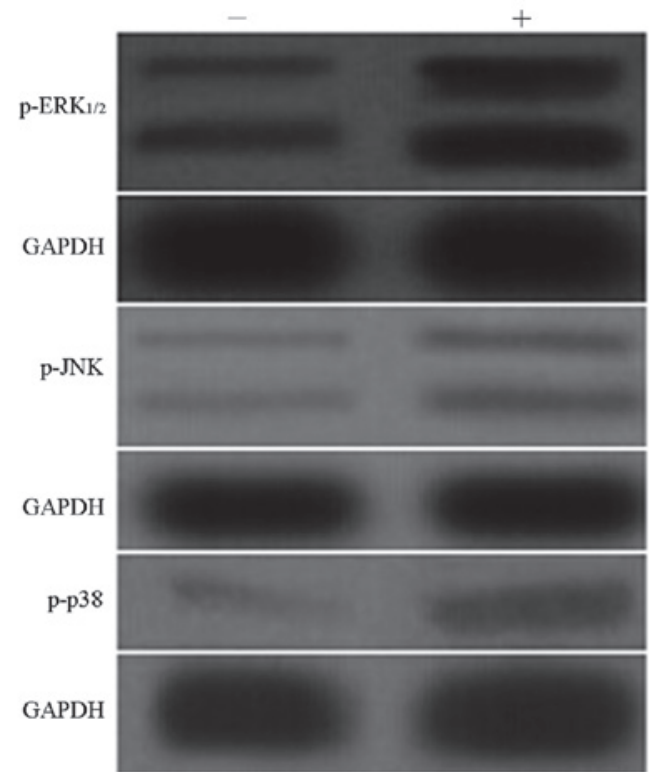

B

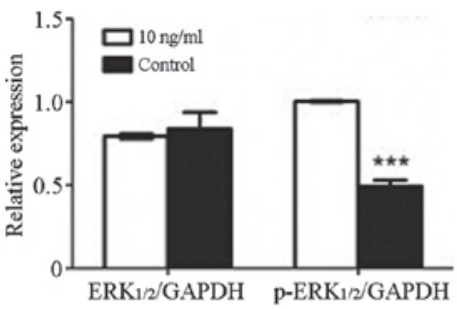

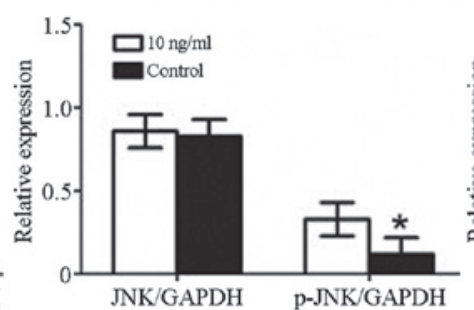
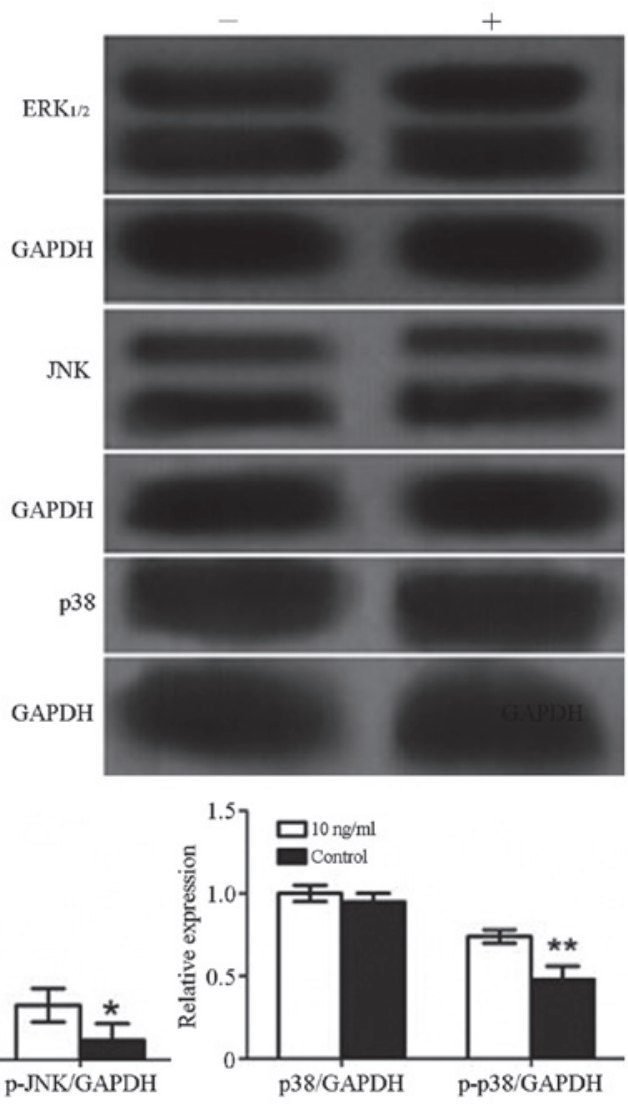

Figure 5. Effects of the treatment of GCTSCs with rhBMP-2 $(10 \mathrm{ng} / \mathrm{ml})$ for $72 \mathrm{~h}$ on BMP signaling pathways. (A) Western blot analysis of the activation of the signaling pathways in GCTSCs. GAPDH served as the internal control; + indicates treated with rhBMP-2 (10 ng/ml) and - indicates control. (B) Bar plots indicating the relative expression of protein in GCTSCs between the control and rhBMP-2-treated groups. Expression levels of p-ERK1/2, p-p38 and p-JNK increased significantly following treatment with rhBMP-2, but the levels of ERK1/2, p38 and JNK were unchanged. Results are means \pm SD of three independent experiments. ${ }^{*} \mathrm{P}<0.05,{ }^{* *} \mathrm{P}<0.01,{ }^{* * * *} \mathrm{P}<0.001$ vs. the control group. rhBMP-2, recombinant human bone morphogenetic protein-2; GCTSC, giant cell tumor of bone stromal cell; p, phospho; ERK, extracellular signal-regulated kinase; JNK, c-Jun-N-terminal kinase. 
compared with the control. The growth of GCTSCs was significantly inhibited compared with the control when treated with all three concentrations of rhBMP-2 for 7 days $(\mathrm{P}<0.001)$, whereas no growth inhibition of GCTSCs compared with the control was observed following the addition of 10,100 or $300 \mathrm{ng} / \mathrm{ml} \mathrm{rhBMP}-2$ for 1 or 3 days. Treatment of GCTSCs with 100 or $300 \mathrm{ng} / \mathrm{ml}$ rhBMP-2 for 1 day induced a slight stimulation of cell growth, but not significantly.

Effects of rhBMP-2 on GCTSC apoptosis and cell cycle distribution. To determine whether BMP-2 affected the cell cycle distribution of GCTSCs, the GCTSCs were incubated with rhBMP-2 (10 $\mathrm{ng} / \mathrm{ml})$ for $48 \mathrm{~h}$ and analyzed using flow cytometry (Fig. 3 ). The cell cycle kinetics demonstrated that there was no significant difference between the control and rhBMP-2 $(10 \mathrm{ng} / \mathrm{ml})$ treatment groups in the percentage of cells in the G0/G1, S and G2/M phases. The inhibition of apoptosis is a critical factor for tumor progression. Therefore, Annexin V-PE/PI staining was evaluated by flow cytometry. Following culture of the GCTSCs with rhBMP-2 $(10 \mathrm{ng} / \mathrm{ml})$ for $48 \mathrm{~h}$, the percentage of apoptotic cells was very similar to that in the untreated control group, indicating that rhBMP-2 did not change the incidence of apoptosis over the 48-h treatment period. However, the percentage of necrotic cells markedly increased in the BMP-2 group compared with the control group ( ${ }^{*} \mathrm{P}<0.05$; Fig. 4A). Notably, after $72 \mathrm{~h}$ of rhBMP-2 treatment, the percentage of apoptotic and necrotic cells was significantly increased in the BMP-2 group compared with the control group ( ${ }^{* *} \mathrm{P}<0.01$; Fig. 4B). Indeed, these data indicate that rhBMP-2 increased the susceptibility of GCTSCs to apoptosis, which corresponds with the results of the MTT assay.

Western blot analysis. To clarify the mechanisms underlying the effects of BMP-2 on GCTSCs, the expression of non-Smad MAPK pathway-associated proteins, including p38, JNK and ERK1/2 were examined. As shown in Fig. 5, following the addition of rhBMP-2 $(10 \mathrm{ng} / \mathrm{ml})$ to GCTSCs for $72 \mathrm{~h}$, the levels of p38, JNK and ERK1/2 detected in exponentially growing GCTSCs were similar to those in the control group, but the expression levels of phospho-p38, phospho-ERK1/2 and phospho-JNK were significantly increased in the rhBMP-2-treated GCTSCs compared with those in the control group.

\section{Discussion}

GCT is a common benign tumor of bone in adults. The use of bone cement with or without phenol or other toxic substances has been widely used as effective adjuvant therapy following the surgical curettage of GCT $(3,5,6,25-28)$. rhBMP-2 is an osteoinductive growth factor that can promote bone formation, and is widely used in fracture nonunions and spine fusion for the treatment of degenerative spinal disorders. Numerous previous studies have shown that rhBMP-2 has a dual role in tumor biology: it functions as a tumor promoter or a tumor suppressor, depending on the type of cell or tissue, the BMP-2 dosage and the presence of other factors that are not yet defined in the microenvironment $(10,13-17,29,30)$. This behavior suggests that in different types of tumor, it acts on a type of cellular homeostatic mechanism through as yet unknown regulatory signaling pathways, such as non-Smad pathways (19-22). For these reasons, surgeons may hesitate to use BMP-2 on their patients for fracture healing or spine fusion. Therefore, further preclinical studies are required to evaluate the effect of BMP-2 on the growth of GCTs to guide its use in patients.

The data from the present study provide the first evidence that BMP-2 has a significant inhibitory effect on tumorigenic GCTSC proliferation at lower concentrations (10 and $100 \mathrm{ng} / \mathrm{ml}$ ) of rhBMP-2, as compared with a higher concentration $(300 \mathrm{ng} / \mathrm{ml})$, for 5 days in vitro. Following treatment for 7 days, the different concentrations of rhBMP-2 exerted similar inhibitory effects on tumorigenic GCTSC proliferation compared with that in the control group. This result is consistent with previous studies that have shown an inhibitory effect of BMP-2 on cancer cell growth, including prostate, breast, myeloma, gastric and colon cancers (13,14,16,17,31-34). However, the present study confirmed in vitro that rhBMP-2 inhibits GCTSC proliferation in a non-dose- and time-dependent manner. In contrast with previous studies which indicated through flow cytometric analysis that the inhibitory effect of BMP-2 on cell growth was due to G1 phase arrest $(13,14)$, the present study showed that there was no difference in the percentage of cells in each phase of the cell cycle between the untreated GCTSCs and those treated with rhBMP-2 for $48 \mathrm{~h}$.

Therefore, the present study confirmed that BMP-2 inhibits cell growth in vitro by inducing apoptosis in GCTSCs. The observed increase in cell apoptosis may be associated with the upregulation of phospho-p38, phospho-ERK1/2 and phospho-JNK, and the stimulation of MAPK signaling pathways.

In conclusion, BMP-2 inhibited GCTSC proliferation through the induction of apoptosis. The results demonstrate that rhBMP-2 is suitable for use as an antineoplastic therapeutic agent for the treatment of GCT.

\section{Acknowledgements}

This study was sponsored by the National Nature Science Foundation of China (grant no. 81172012) and Guangdong Natural Science Foundation (grant no. S2011010001062).

\section{References}

1. Mendenhall WM, Zlotecki RA, Scarborough MT, Gibbs CP and Mendenhall NP: Giant cell tumor of bone. Am J Clin Oncol 29: 96-99, 2006.

2. Gamberi G, Serra M, Ragazzini P, Magagnoli G, Pazzaglia L, Ponticelli F, Ferrari C, Zanasi M, Bertoni F, Picci P and Benassi MS: Identification of markers of possible prognostic value in 57 giant cell tumors of bone. Oncol Rep 10: 351-356, 2003.

3. Trieb K, Bitzan P, Lang S, Dominkus M and Kotz R: Recurrence of curetted and bone-grafted giant-cell tumours with and without adjuvant phenol therapy. Eur J Surg Oncol 27: 200-202, 2001.

4. Campanacci M, Baldini N, Boriani S and Sudanese A: Giant-cell tumor of bone. J Bone Joint Surg Am 69: 106-114, 1987.

5. Tse LF, Wong KC, Kumta SM, Huang L, Chow TC and Griffith JF: Bisphosphonates reduce local recurrence in extremity giant cell tumor of bone: A case-control study. Bone 42: 68-73, 2008.

6. Gibbs CP, Lewis VO and Peabody T: Beyond bone grafting: Techniques in the surgical management of benign bone tumors. Instr Course Lect 54: 497-503, 2005. 
7. Zheng MH, Robbins P, Xu J, Huang L, Wood DJ and Papadimitriou JM: The histogenesis of giant cell tumour of bone: A model of interaction between neoplastic cells and osteoclasts. Histol Histopathol 16: 297-307, 2001.

8. Hopkins DR, Keles S and Greenspan DS: The bone morphogenetic protein 1/Tolloid-like metalloproteinases. Matrix Biol 26: 508-523, 2007.

9. Senta H, Park H, Bergeron E, Drevelle O, Fong D, Leblanc E, Cabana F, Roux S, Grenier G and Faucheux N: Cell responses to bone morphogenetic proteins and peptides derived from them: Biomedical applications and limitations. Cytokine Growth Factor Rev 20: 213-222, 2009.

10. Singh A and Morris RJ: The Yin and Yang of bone morphogenetic proteins in cancer. Cytokine Growth Factor Rev 21: 299-313, 2010

11. Barboza E, Caúla A and Machado F: Potential of recombinant human bone morphogenetic protein-2 in bone regeneration. Implant Dent 8: 360-367, 1999.

12. Hogan BL: Bone morphogenetic proteins: Multifunctional regulators of vertebrate development. Genes Dev 10: 1580-1594, 1996

13. Chen A, Wang D, Liu X, He S, Yu Z and Wang J: Inhibitory effect of BMP-2 on the proliferation of breast cancer cells. Mol Med Rep 6: 615-620, 2012

14. Ye S, Park BH, Song KJ, Kim JR, Jang KY, Park HS, Bae JS Brochmann EJ, Wang JC, Murray SS and Lee KB: In vivo inhibition of bone morphogenetic protein-2 on breast cancer cell growth. Spine (Phila Pa 1976) 38: E143-E150, 2013.

15. Langenfeld EM, Kong Y and Langenfeld J: Bone morphogenetic protein 2 stimulation of tumor growth involves the activation of Smad-1/5. Oncogene 25: 685-692, 2006.

16. Kokorina NA, Lewis JS Jr, Zakharkin SO, Krebsbach PH and Nussenbaum B: rhBMP-2 has adverse effects on human oral carcinoma cell lines in vivo. Laryngoscope 122: 95-102, 2012.

17. Molina CA, Sarabia-Estrada R, Gokaslan ZL, Witham TF, Bydon A, Wolinsky JP and Sciubba DM: Delayed onset of paralysis and slowed tumor growth following in situ placement of recombinant human bone morphogenetic protein 2 within spine tumors in a rat model of metastatic breast cancer. J Neurosurg Spine 16: 365-372, 2012

18. Haÿ E, Lemonnier J, Fromigué O, Guénou H and Marie PJ: Bone morphogenetic protein receptor IB signaling mediates apoptosis independently of differentiation in osteoblastic cells J Biol Chem 279: 1650-1658, 2004.

19. Kimura N, Matsuo R, Shibuya H, Nakashima K and Taga T: BMP2-induced apoptosis is mediated by activation of the TAK1-p38 kinase pathway that is negatively regulated by Smad6. J Biol Chem 275: 17647-17652, 2000.

20. Lee KS, Hong SH and Bae SC: Both the Smad and p38 MAPK pathways play a crucial role in Runx 2 expression following induction by transforming growth factor-beta and bone morphogenetic protein. Oncogene 21: 7156-7163, 2002.
21. Moustakas A and Heldin CH: Non-Smad TGF-beta signals J Cell Sci 118: 3573-3584, 2005.

22. Guicheux J, Lemonnier J, Ghayor C, Suzuki A, Palmer G and Caverzasio J: Activation of p38 mitogen-activated protein kinase and c-Jun-NH2-terminal kinase by BMP-2 and their implication in the stimulation of osteoblastic cell differentiation. J Bone Miner Res 18: 2060-2068, 2003.

23. Huang L, Teng XY, Cheng YY, Lee KM and Kumta SM: Expression of preosteoblast markers and Cbfa-1 and Osterix gene transcripts in stromal tumour cells of giant cell tumour of bone. Bone 34: 393-401, 2004

24. Kudo N, Ogose A, Ariizumi T, Kawashima H, Hotta T, Hatano H, Morita T, Nagata M, Siki Y, Kawai A, et al: Expression of bone morphogenetic proteins in giant cell tumor of bone. Anticancer Res 29: 2219-2225, 2009.

25. Su YP, Chen WM and Chen TH: Giant-cell tumors of bone: An analysis of 87 cases. Int Orthop 28: 239-243, 2004.

26. Saiz P, Virkus W, Piasecki P, Templeton A, Shott S and Gitelis S: Results of giant cell tumor of bone treated with intralesional excision. Clin Orthop Related Res 424: 221-226, 2004.

27. Ward WG Sr and Li G: Customized treatment algorithm for giant cell tumor of bone: Report of a series. Clin Orthop Relat Res 397: 259-270, 2002

28. Turcotte RE, Wunder JS, Isler MH, Schachar N, Masri BA, Moreau G and Davis AM; Canadian Sarcoma Group: Giant cell tumor of bone. Giant cell tumor of long bone: A Canadian sarcoma group study. Clin Orthop Relat Res 397: 248-258, 2002.

29. Kleeff J, Maruyama H, Ishiwata T, Sawhney H, Friess H, Büchler MW and Korc M: Bone morphogenetic protein 2 exerts diverse effects on cell growth in vitro and is expressed in human pancreatic cancer in vivo. Gastroenterology 116: 1202-1216, 1999.

30. Ide H, Yoshida T, Matsumoto N, Aoki K, Osada Y, Sugimura T and Terada M: Growth regulation of human prostate cancer cells by bone morphogenetic protein-2. Cancer Res 57: 5022-5027, 1997.

31. Beck SE, Jung BH, Fiorino A, Gomez J, Rosario ED, Cabrera BL, Huang SC, Chow JY and Carethers JM: Bone morphogenetic protein signaling and growth suppression in colon cancer. Am J Physiol Gastrointest Liver Physiol 291: G135-G145, 2006.

32. Wen XZ, Miyake S, Akiyama Y and Yuasa Y: BMP-2 modulates the proliferation and differentiation of normal and cancerous gastric cells. Biochem Biophys Res Commun 316: 100-106, 2004.

33. Brubaker KD, Corey E, Brown LG and Vessella RL: Bone morphogenetic protein signaling in prostate cancer cell lines. J Cell Biochem 91: 151-160, 2004.

34. Pouliot F, Blais A and Labrie C: Overexpression of a dominant negative type II bone morphogenetic protein receptor inhibits the growth of human breast cancer cells. Cancer Res 63: 277-281, 2003. 